\title{
Body condition scoring in relation to changes in body weight and performance in Belgian Blue double-muscled beef cows
}

\author{
Leo O. Fiems*, Wim VAn CAElenbergh, Sam De CAMPENEere, \\ Daniël L. DE BRABANDER
}

CLO-Department Animal Nutrition and Husbandry, Scheldeweg 68, 9090 Melle, Belgium

(Received 1 July 2005 - Accepted 6 January 2006)

\begin{abstract}
The relationship between the body condition in Belgian Blue double-muscled cows and the performance of cows and calves has been studied over a 5-year period. One hundred and twenty-six cows, with a mean initial parity of $1.6 \pm 1.1$ were involved. During each winter, they were fed 100, 90, 80 or $70 \%$ of their energy requirements (140-day restriction period). At the end of April, all cows were turned out on pasture in identical circumstances (re-alimentation period). Half of the cows were suckled by their offspring; the other cows were dried off following calving and colostrum collection. Body condition score (BCS; scale 0 to 5 ) was determined at the start and end of the restriction period and the re-alimentation period, at monthly intervals and at calving. Two hundred and thirteen parturitions were involved, of which $63 \%$ occurred during the first half of the year. BCS (mean of monthly observations) was lower $(P<0.001)$ in primiparous $(1.45)$ cows than in cows with two (1.69) or more parturitions (1.81). BCS (mean of monthly observations) was lower in suckling cows $(1.51)$ than in dry cows $(1.79 ; P<0.001)$. BCS (mean of monthly observations) was reduced by energy restriction from 1.75 to $1.56(P<0.001)$. BCS-change during the restriction and re-alimentation periods was related to body weight change $\left(\mathrm{R}^{2}=0.538\right)$. BCSchange was negative during the restriction period, but it was more than compensated for during the re-alimentation period. BCS at calving was not related to the length of the subsequent calving interval. Cows with a BCS less than 1.5 at calving, yielded less milk and calf performance was reduced when compared with those with a BCS over 1.5. The dams of calves that died at birth had a lower BCS at calving (1.45) than the dams of surviving calves $(1.75 ; P=0.044)$. Open cows at 9 months postpartum had a higher BCS at calving (1.78) than cows that became pregnant within 9 months postpartum $(1.50 ; P<0.001)$. Consequently, it is difficult to define a universal optimum BCS for double-muscled cows, resulting in a maximal milk production and calf growth, a low calf loss and cow culling rate and a calving interval of approximately one year.
\end{abstract}

body condition / body weight / cow / double-muscling / calving interval / milk yield / calf performance

Résumé - Relation entre la note d'état d'engraissement et les performances des vaches Blanc Bleu Belge culardes. La relation entre la note d'état d'engraissement (NEE) des vaches et les performances des vaches et des veaux a été vérifiée avec cent vingt-six vaches Blanc Bleu Belge culardes pendant cinq années. Les animaux avaient une parité moyenne de 1,6 $\pm 1,1$ au début. Pendant chaque hiver, elles ont été affouragées à 100, 90, 80 ou $70 \%$ de leurs besoins énergétiques

\footnotetext{
*Corresponding author: 1.fiems@clo.fgov.be
} 
(140 jours ; période de restriction). Toutes les vaches ont été mises au pâturage dans des conditions identiques à partir de la fin avril (période de compensation). La moitié des vaches ont allaité leur veau, tandis que les autres vaches ont été taries après collection du colostrum. La NEE (0-5) était déterminée au début et à la fin de la période de restriction et de la période de compensation, chaque mois et aussi au moment du vêlage. Il y avait 213 vêlages, dont $63 \%$ pendant la première moitié de l'année. La NEE (moyenne des observations) était plus faible $(P<0,001)$ chez les primipares $(1,45)$ que chez les vaches à deux $(1,69)$ ou plus de vêlages $(1,81)$. La NEE (moyenne des observations) était plus faible chez les vaches allaitantes $(1,51)$ que les vaches taries $(1,79 ; P<0,001)$. La NEE (moyenne des observations) a été réduite de 1,75 à 1,56 par une restriction énergétique $(P<$ $0,001)$. Le changement de la NEE pendant les périodes de restriction ou de compensation était lié au changement du poids $\left(\mathrm{R}^{2}=0,538\right)$. Le changement de la NEE était négatif pendant la période de restriction, mais il était plus que compensé pendant la période de compensation. La NEE au vêlage n'était pas clairement liée avec l'intervalle vêlage-vêlage suivant. Une NEE au vêlage inférieure à 1,5 a diminué la production laitière et la croissance des veaux. La NEE au vêlage des mères des veaux morts à l'âge de 16 semaines $(1,45)$ était plus faible que chez les mères des veaux en vie $(1,75 ; P=0,044)$. Les vaches non-gestantes 9 mois après le dernier vêlage avaient une NEE au vêlage plus élevée $(1,78)$ que les vaches en gestation 9 mois après le dernier vêlage $(1,50$; $P<0,001)$. Par conséquent, il est difficile de définir une NEE optimale universelle pour les vaches culardes, qui conduise à une production laitière et une croissance du veau maximales, des taux faibles de mortalité des veaux et de reforme des vaches, et un intervalle vêlage-vêlage d'à peu près un an.

état d'engraissement / poids vif / vache / culard / intervalle vêlage-vêlage / production laitière / performance de veau

\section{INTRODUCTION}

Several authors $[16,25]$ have proposed a body condition scoring system to estimate body fat depots. The systems vary from a 6 to a 9-point scale and are aimed at estimating subcutaneous fat cover. One system was introduced for fatter AngloSaxon breeds [16] as well as leaner continental breeds [1]. However, none of the existing systems was designed for use in double-muscled cows. Therefore, its applicability in the latter animals may be questionable, since ribs, hips, backbones and tail head tend to be embedded in a muscle mass rather than in adipose tissue. Nevertheless, a good relationship was found between BCS (body condition score) in double-muscled cows and the chemical composition of the empty body weight [9].

Bellows and Short [4] stated that a reduced pre-calving feeding level decreased BCS at calving and reduced the birth weight of the calf. Wright et al. [26], Richards et al. [20] and Laflamme and Connor [14] reported a negative correlation between BCS at calving and the post- partum anoestrous interval. According to Houghton et al. [12], pregnancy rate was affected by cow BCS at parturition combined with a change in BCS prior to breeding. However, as concluded by Wright and Russel [27], BCS may be a cheap and nondestructive method to assess body composition, making it a useful aid to the management of suckler cows.

The primary objective of this study was to examine the effects of BCS on body weight change and calving interval of Belgian Blue double-muscled beef cows and birth weight and performance of their calves.

\section{MATERIALS AND METHODS}

One hundred and twenty-six Belgian Blue double-muscled (BBDM) cows were used in an experiment that commenced in December 1998 and ended in the spring 2004. The parity at the start of the experiment averaged $1.6 \pm 1.1$, ranging from 1 to 6 . At the onset, the cows were divided into four comparable groups (E100, 
E90, E80 and E70), based on BW (body weight), parity and BCS. During each indoor period (140 days commencing on the first Thursday of December each year; restriction period) the cows in the respective groups received $100,90,80$ or $70 \%$ of their energy (E) requirements. The basic diet consisted of maize silage and straw (80/20 on a dry matter basis) and $0.5 \mathrm{~kg}$ of a mineral-vitamin-premix. It was supplemented with an appropriate amount of soybean meal and/or urea to meet protein requirements, depending on the physiological state of the cow (lactating, dry or gestating). This restriction period was followed by a re-alimentation period, where cows were turned out to similar pastures at the end of April each year. The cows were grazed in different groups to prevent inbreeding, since service bulls were used for reproduction. Suckling cows were grazed separately to make calf care easier. In case of a lack of grass towards the end of the grazing period, they were confined and received a maize silage diet, fed at $125 \%$ of their energy requirements.

No oestrus synchronisation was applied. The calvings occurred throughout the year, with $36,27,20$ and $17 \%$ of the parturitions during the respective quarters of the year. Half of the cows were suckled by their calves, while the remainder were dried off after calving and colostrum collection. These calves were artificially reared. Individual milk intake of suckling calves was measured every four weeks by the weigh-suckle-weigh technique [2]. The cows were culled if they were not pregnant within nine months after the last parturition (based on rectal palpation). Other reasons for culling were perimetrial adhesions and mortality.

BCS was determined by at least two technicians at the start and the end of the restriction and the re-alimentation periods, and at calving. It was also recorded monthly in the course of the aforementioned periods. Before the experiment, technicians received an ad hoc training after two authors had followed training at INRA-Theix, France. The BCS-system has been described by Agabriel et al. [1] and ranged between 0 (extremely thin) and 5 (very fat). This system was preferred, since it has been tested in continental European beef breeds, such as Charolais and Limousin.

The effects of parity, calf rearing method and energy restriction on BCS were investigated. The relationship between BCS-change and BW-change during the restriction and the re-alimentation periods was also investigated. BW was the mean of weight records taken on two consecutive days at the start and the end of the period of restriction and at the end of the re-alimentation period. In addition to the observed BW, an individual corrected BW was calculated based on the total weight of the foetus, foetal fluids and membranes (conceptus weight, $\mathrm{CW}_{t}$ ) at day $\mathrm{t}$ after conception, according to the model of Ferrell et al. [8]: $\mathrm{CW}_{t}=470.1 \mathrm{e}^{(0.0217-0.0000161 t) t}$, multiplied by $\Delta \mathrm{BW} / 60.2 . \Delta \mathrm{BW}$ was the individual difference between pre- and postcalving cow BW, and 60.2 was the mean $\mathrm{CW}_{t}$ at parturition in the experiment of Ferrell et al. [8]. The effect of BCS at calving on calving interval and calf performance from birth to 16 weeks of age was examined. Therefore, the cows were divided into three classes according to their BCS at calving: group 1: $\mathrm{BCS} \leq 1.5$, group 2: $1.5<\mathrm{BCS} \leq 2$ and group 3: $\mathrm{BCS}$ $>2.0$ in order to determine the effects of $\mathrm{BCS}$ at calving on cow milk yield and calf performance.

The data were analysed by analysis of variance, regression analysis or Chi-square test using SPSS [23].

\section{RESULTS}

The 126 cows yielded 3870 monthly values of BCS. Besides, 546 values were generated at the start and the end of the 
Table I. Effect of energy level in winter, parity and calf rearing method on mean body condition score (BCS) and body weight (BW, kg).

\begin{tabular}{lcccc}
\hline & & No. of observations & BCS & BW \\
\hline Energy level (E, \%) & 100 & 971 & $1.75^{\mathrm{a}}$ & $651^{\mathrm{a}}$ \\
& 90 & 1026 & $1.69^{\mathrm{b}}$ & $656^{\mathrm{a}}$ \\
& 80 & 919 & $1.56^{\mathrm{c}}$ & $639^{\mathrm{b}}$ \\
& 70 & 954 & $1.61^{c}$ & $642^{\mathrm{b}}$ \\
\hline Parity (P) & 1 & 1251 & $1.45^{\mathrm{a}}$ & $591^{\mathrm{a}}$ \\
& 2 & 1212 & $1.69^{\mathrm{b}}$ & $659^{\mathrm{b}}$ \\
& $\geq 3$ & 1407 & $1.81^{c}$ & $691^{c}$ \\
\hline Calf rearing & Suckling & 1802 & $1.51^{\mathrm{a}}$ & $629^{\mathrm{a}}$ \\
method (CRM) & Rearing & 2068 & $1.79^{\mathrm{b}}$ & $665^{\mathrm{b}}$ \\
\hline Pooled SD & & 0.58 & 69 \\
\hline Significance & Energy level & & $<0.001$ & $<0.001$ \\
& Parity & & $<0.001$ & $<0.001$ \\
& Calf rearing method & & $<0.001$ & $<0.001$ \\
& E $\times$ P & & $<0.001$ & $<0.001$ \\
& E $\times$ CRM & & 0.045 & $<0.001$ \\
& P $\times$ CRM & & 0.070 & 0.012 \\
\hline
\end{tabular}

a Values per factor within columns with the same superscripts are not different $(P>0.05)$.

restriction period and the re-alimentation period. This figure was higher than twice the number of cows involved. First, the calving interval was longer than one year; so, this interval did not correspond with the joint duration of restriction and re-alimentation periods. Another reason was that data from culled cows that had a complete restriction or re-alimentation period after the last parturition were also included. Two hundred thirteen calves were born out of these 126 cows and 8 abortions took place. The abortions were equalised with parturitions with regards to parity.

The values of BCS were correlated among evaluators $(P<0.001)$ and ranged between 0.40 and 0.85 . The values presented here are means of all evaluators.

The data were divided into three classes, according to cow parity: 1 (primiparous cows), 2 (cows with two parturitions) and 3 (cows with three or more parturitions). The mean parity of cows in group 3 averaged 3.6 \pm 0.8 . The means of BCS and BW
(Tab. I) were significantly affected by energy level in the winter $(P<0.001)$, parity $(P<0.001)$ and calf rearing method $(P<0.001)$. Restricted cows were lighter and had a lower BCS. BW was similar for E100 and E90, and for E80 and E70, but weights of E100 and E90 were different from those of E80 and E70. BCS was similar for E80 and E70, while these two groups and E100 and E90 were different among themselves. BCS and BW were different between each parity class. Suckled cows had a lower average BCS and BW than non-suckled ones. Interactions were found between these three factors $(P \leq 0.070)$. The relationship between the $\mathrm{BCS}$-change and $\mathrm{BW}$-change from the start to the end of each restriction period and each subsequent re-alimentation period for primiparous cows (194 observations), second calving cows (188 observations), or multiparous cows (164 observations), and all cows (546 observations) is shown in Figure 1. About 0.55 of the variation in 

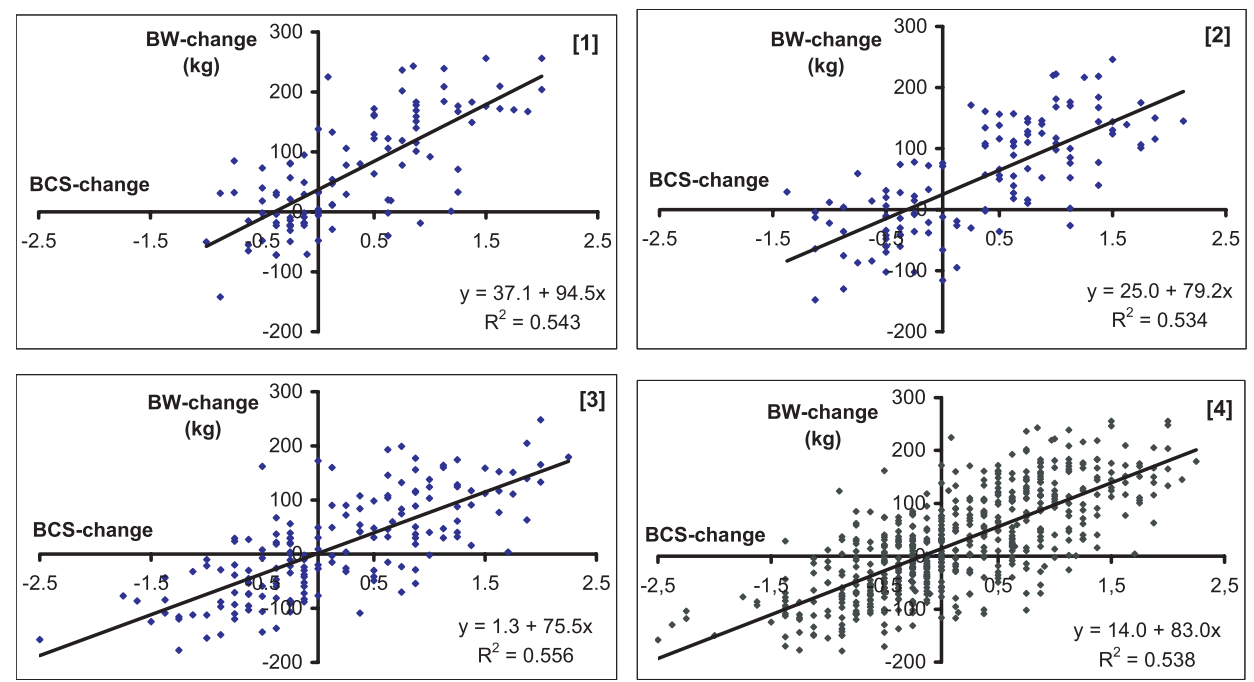

Figure 1. Relationship between the BCS-change and BW-change during the restriction and the subsequent re-alimentation period for 1: primiparous cows; 2: cows with two parturitions, 3: cows with three and more parturitions, 4: all observations.

BW could be explained by the variation in BCS. A similar effect was found for each group of cows. The relationship could not be improved by the use of the cow BW corrected for the gravid uterus.

The effect of period (restriction vs. realimentation), energy level (E100 to E70), parity (class 1-3) and calf rearing method on change of BCS and BW from the start to the end of the restriction period and the subsequent re-alimentation period is given in Table II. Significant differences occurred for both parameters between periods as a consequence of energy restriction during the winter period and compensatory growth during the subsequent grazing period. The loss of BCS and BW during the restriction period was more than compensated for during the re-alimentation period. Energy level and calf rearing method affected BCS and BW at the start and end of the restriction period and the subsequent re-alimentation period, but changes of BCS and BW were not different. BCSchange and BW-change were mostly not affected by parity, except that BW-change was larger in primiparous than in cows with three or more parturitions. There was a tendency $(P=0.098)$ for a smaller BCSchange in primiparous cows than in cows with three or more parturitions. Most interactions between period, energy level, parity and calf rearing method (not shown in Tab. II) were not significant. Significant interactions $(P<0.05)$ occurred between period and energy level, period and parity, and period, energy level and calf rearing method with regards to BCS-change, and also between period and energy level, period and calf rearing method, and period, energy level, parity and calf rearing method with regards to BW-change.

The calving interval averaged 419 days, and was not related to the BCS at calving, neither for the whole data set, nor when examined according to the calf rearing method or cow parity or energy level $\left(\mathrm{R}^{2} \leq 0.050\right)$. However, the effect of BCS at calving on subsequent calving interval may be masked by the fact that the cows 
Table II. Body condition score (BCS) and body weight (BW, kg) at the start and end of the restriction and the re-alimentation periods, and changes during these periods.

\begin{tabular}{|c|c|c|c|c|c|c|c|}
\hline & \multirow{2}{*}{ No. of observations } & \multicolumn{3}{|c|}{ BCS } & \multicolumn{3}{|c|}{$\mathrm{BW}$} \\
\hline & & Start & End & Change & Start & End & Change \\
\hline \multicolumn{8}{|l|}{ Period } \\
\hline Restriction & 293 & $1.89^{\mathrm{a}}$ & $1.51^{\mathrm{a}}$ & $-0.38^{\mathrm{a}}$ & $666^{\mathrm{a}}$ & $623^{\mathrm{a}}$ & $-43^{\mathrm{a}}$ \\
\hline Re-alimentation & 253 & $1.43^{\mathrm{b}}$ & $2.11^{\mathrm{b}}$ & $0.68^{\mathrm{b}}$ & $599^{\mathrm{b}}$ & $699^{b}$ & $100^{\mathrm{b}}$ \\
\hline \multicolumn{8}{|l|}{ Energy level } \\
\hline $100 \%$ & 138 & $1.76^{\mathrm{a}}$ & $1.93^{\mathrm{a}}$ & $0.17^{\mathrm{a}}$ & $640^{\mathrm{a}}$ & $672^{\mathrm{a}}$ & $32^{\mathrm{a}}$ \\
\hline $90 \%$ & 144 & $1.73^{\mathrm{ab}}$ & $1.89^{\mathrm{a}}$ & $0.16^{\mathrm{a}}$ & $643^{\mathrm{a}}$ & $670^{\mathrm{a}}$ & $27^{\mathrm{a}}$ \\
\hline $80 \%$ & 131 & $1.54^{\mathrm{c}}$ & $1.69^{\mathrm{b}}$ & $0.15^{\mathrm{a}}$ & $619^{\mathrm{b}}$ & $648^{\mathrm{b}}$ & $29^{\mathrm{a}}$ \\
\hline $70 \%$ & 133 & $1.60^{\mathrm{bc}}$ & $1.73^{\mathrm{b}}$ & $0.13^{\mathrm{a}}$ & $627^{\mathrm{ab}}$ & $653^{\mathrm{b}}$ & $26^{\mathrm{a}}$ \\
\hline \multicolumn{8}{|l|}{ Parity } \\
\hline 1 & 194 & $1.51^{\mathrm{a}}$ & $1.59^{\mathrm{a}}$ & $0.08^{\mathrm{a}}$ & $576^{\mathrm{a}}$ & $612^{\mathrm{a}}$ & $36^{\mathrm{a}}$ \\
\hline 2 & 188 & $1.69^{\mathrm{b}}$ & $1.86^{\mathrm{b}}$ & $0.17^{\mathrm{a}}$ & $645^{\mathrm{b}}$ & $672^{\mathrm{b}}$ & $27^{\mathrm{ab}}$ \\
\hline$\geq 3$ & 164 & $1.78^{\mathrm{c}}$ & $1.98^{\mathrm{b}}$ & $0.20^{\mathrm{a}}$ & $676^{\mathrm{c}}$ & $698^{c}$ & $22^{\mathrm{b}}$ \\
\hline \multicolumn{8}{|l|}{ Calf rearing method } \\
\hline Suckling & 277 & $1.57^{\mathrm{a}}$ & $1.71^{\mathrm{a}}$ & $0.14^{\mathrm{a}}$ & $617^{\mathrm{a}}$ & $643^{\mathrm{a}}$ & $26^{\mathrm{a}}$ \\
\hline Rearing & 269 & $1.75^{\mathrm{b}}$ & $1.91^{\mathrm{b}}$ & $0.16^{\mathrm{a}}$ & $647^{\mathrm{b}}$ & $679^{\mathrm{b}}$ & $32^{\mathrm{a}}$ \\
\hline Pooled SD & & 0.69 & 0.60 & 0.64 & 68.6 & 61.1 & 60.3 \\
\hline \multicolumn{8}{|l|}{ Significance } \\
\hline Period & & $<0.001$ & $<0.001$ & $<0.001$ & $<0.001$ & $<0.001$ & $<0.001$ \\
\hline Energy level & & 0.008 & 0.002 & 0.978 & 0.017 & 0.002 & 0.874 \\
\hline Parity & & $<0.001$ & $<0.001$ & 0.200 & $<0.001$ & $<0.001$ & 0.069 \\
\hline Calf rearing method & & $<0.001$ & $<0.001$ & 0.822 & $<0.001$ & $<0.001$ & 0.276 \\
\hline
\end{tabular}

${ }^{a}$ Values per factor within columns with the same superscripts are not different $(P>0.05)$.

were eliminated if they were not pregnant within nine months after the last parturition. Therefore, data were re-allocated into three classes: data from cows that were rebred within nine months after the last parturition $(\mathrm{n}=218)$, data from cows that were not re-bred within nine months after the last parturition (open cows; $\mathrm{n}=$ $50)$, and data from cows that aborted $(\mathrm{n}=$ 8). BCS at calving averaged $1.50 \pm 0.47$, $1.78 \pm 0.50$ and $1.72 \pm 0.49$, respectively. The values were different between cows that were re-bred or not within nine months after the last parturition $(P<0.001)$, while cows that aborted did not differ significantly from the other groups. An investiga- tion of the cows, culled for the reason that they were not pregnant nine months after the last parturition, did not show an effect of energy level $(P=0.895)$ on mean parity at culling $(3.1 \pm 1.4)$. Calf rearing method had no influence on frequency of culling $(P=0.785)$. Dividing data into 3 classes according to BCS at calving resulted in more open cows 9 months after parturition, when BCS was higher $(P=0.018)$. In class 1 (BCS $<1.5 ; \mathrm{n}=124), 2$ (BCS 1.5 to $2 ; \mathrm{n}=96)$ and $3(\mathrm{BCS}>2 ; \mathrm{n}=40)$ there were $12.9,20.8$ and $32.5 \%$ of cows, respectively, which were not pregnant. The corresponding values for BCS at calving were $1.17,1.73$ and 2.34 . 
Table III. Effect of body condition score (BCS) at calving on milk yield of the dams (kg per d) and average daily gain of the calves (birth - weaning, kg per d).

\begin{tabular}{lccccc}
\hline & \multicolumn{3}{c}{ BCS-class } & Pooled & $P$-value \\
\cline { 2 - 4 } & $\leq 1.5$ & $1.5<$ BCS $\leq 2$ & $>2$ & SD & \\
\hline No. of cow-calf pairs & 62 & 41 & 17 & & \\
Mean BCS & $1.23^{\mathrm{a}}$ & $1.74^{\mathrm{b}}$ & $2.42^{\mathrm{c}}$ & 0.22 & $<0.001$ \\
Dam milk yield* & $6.54^{\mathrm{a}}$ & $7.60^{\mathrm{b}}$ & $7.54^{\mathrm{ab}}$ & 1.62 & 0.051 \\
Calf daily gain* & $0.90^{\mathrm{a}}$ & $1.00^{\mathrm{b}}$ & $0.96^{\mathrm{ab}}$ & 0.16 & 0.014 \\
\hline
\end{tabular}

${ }^{\text {a }}$ Values with the same superscripts are not different $(P>0.05)$.

* Cow parity and calf sex as covariates.

The birth weight of all calves averaged $52.3 \mathrm{~kg}$ and was not related to dam BCS at calving $\left(R^{2}=0.003\right)$. Eleven calves were lost within 16 weeks after birth. One of the calves was crushed by the dam within 24 hours after birth $(E=90 \%)$. Other losses were due to stillbirth $(n=1)$, perinatal death $(\mathrm{n}=3)$ or death in the course of this 16 week-period because of illness $(\mathrm{n}=6)$. Four calves with illness died between day one and one week after birth. The dams of the calves lost before the age of 16 weeks had a lower BCS at calving than the dams of surviving calves: $1.45 \mathrm{vs}$. $1.75 ; P=0.044$. Most calves died within $\mathrm{E}=70 \%$ (6 of 54 calves born). Within $\mathrm{E}$ $80 \%(\mathrm{n}=51), 90 \%(\mathrm{n}=55)$, or $100 \%$ $(\mathrm{n}=53), 2,1$ and 1 calves were lost, respectively. The crushed calf was not included. There was a tendency for a higher calf loss when the energy level was reduced $(P=0.075)$. BCS-class (BCS at calving) also affected calf losses. Out of 77,88 and 47 births within the respective classes, 6, 2 and 2 calves died before an age of 16 weeks, or 7.8, 2.3 and $4.3 \%$, respectively $(P=0.245)$.

Daily mean milk yield (milk intake by the calf) was $7.0 \pm 2.2 \mathrm{~kg}$. Within the cow-calf pairs, dam BCS at calving only showed a small positive correlation with calf milk intake $(r=0.314)$ and average daily gain $(r=0.303)$. Nevertheless, a division of the suckling cows into classes according to BCS at calving resulted in a higher milk yield for cows of class 2 and an improved average daily gain of the calves (Tab. III). To investigate if BCS at calving exerted a positive affect on calf vigour, daily gain was also calculated with milk yield as the covariate. This analysis showed no clear effect of dam BCS on calf live-weight gain $(P=0.219)$.

\section{DISCUSSION}

The present study shows that the mean BCS in BBDM cows is considerably lower than that reported for other breeds, using a comparable BCS-system [12, 26]. It also confirms that the use of a BCS, originally designed for non-double-muscled cattle, can contribute significantly to a good management of BBDM cows, regardless of their low level of body fatness.

The lower BCS of primiparous cows and the smaller change of BCS observed in this study were in accordance with the estimation of body composition of BBDM cows [9]. On the contrary, a larger BWchange was found in these cows. This was not unexpected, since the age at first calving averaged 830 days, meaning that these cows were not yet full-grown. So, BWchange was characterised by a markedly lower fat deposition in these young cows. Boadi and Price [7] also reported that older cows were heavier and had a higher BCS than young cows. 
BCS may offer a good indication of body reserve tissues, since $\mathrm{BW}$ rises with increasing BCS. The relationship seemed valid in young cows as well as in mature cows. When there was no BCS-change, primiparous cows and cows with two calvings showed an increase of BW. On the contrary, there was hardly a BW-change at a constant BCS in older cows (Fig. 1), which is a reflection of the fact that mature BW was achieved in these cows. Nevertheless, Table II shows that BW increased by $22 \mathrm{~kg}$ in older cows. This may not be due to the age of the cows, but it may be provoked by better condition, since BCS-change averaged 0.20 units.

The energy restriction during the indoor period, followed by a catch-up period on pasture, clearly showed a cyclic change of BW and BCS. Consequently, BBDM cows were also able to mobilise body reserves during periods of undernutrition, and to recover the lost BW and energy reserve afterwards. However, the catabolism of body reserves can not go on without impunity, since dams of lost calves had a lower BCS at calving than dams of surviving calves $(P=0.044)$.

It can be concluded from Figure 1 that one unit increase in BCS corresponds with a gross increase of weight of 95, 79 and $76 \mathrm{~kg}$, respectively in primiparous cows, second calving cows and multiparous cows. In addition to cow BW, this change included the weight of foetus, foetal membranes and fluids for some cows. The equivalent BW increase, corrected for gestation, amounts to 81.5, 74.5 and $73.5 \mathrm{~kg}$. It is surprising that the relationship between BCS-change and BWchange, corrected for gestation, was not improved, but no explanation can be given. However, this statement makes it easier to apply BCS in practice without the need for a weight correction during pregnancy. Wright and Russel [27] reported that one unit change in BCS corresponded with a range of 61 to $110 \mathrm{~kg} \mathrm{BW}$ in non-pregnant mature cows of different genotypes. The approach in the current study and in the one of Wright and Russel [27] was slightly different. Data analysis was based on a regression between $\mathrm{BCS}$-change and $\mathrm{BW}$ change, or a regression between BCS and BW, respectively. However, some components of non-adipose body growth are included within the estimate of BW-change in both cases $[9,28]$. While only mature cows were involved in the experiment of Wright and Russel [28], about one third of the data were from primiparous cows in our experiment. As reported previously [9], the empty body of younger cows contained more protein and tended to have less fat.

Calving interval was relatively long in our experiment in comparison with most literature data. A reason for this longer interval may be due to caesarean at parturition and the development of perimetrial adhesions as a consequence [24]. Calving interval was not related to BCS at calving in our study. However, a lot of experiments showed that a BCS at calving lower than 5 on a 9-point scale $[5,19,21,22]$ or lower than 3 on a 6 -point scale $[12,13]$ resulted in a longer calving interval, or a longer anoestrus period $[14,15,20,26]$. Our results suggest an opposite effect of BCS on fertility: open cows at nine months postpartum had a higher BCS at calving. Bearden and Fuquay [3] mentioned that excessive energy intake may provoke a low conception rate and abortion. Houghton et al. [12] reported that cows with a BCS at breeding of more than 3 had over a 29-percentage reduction in first service conception rate than thinner cows. Excessive energy intake will increase BCS. It is clear that a BCS of 2 in double-muscled cows can not be labelled as a consequence of an excessive energy intake.

In addition to the effect of BCS on calving interval reported in the literature, a greater BCS at calving has resulted in calves with a heavier birth weight $[12,22]$. 
Morrison et al. [17], however, found no effect of BCS on calf birth weight, which is in accordance with our findings.

Experiments dealing with the effect of $\mathrm{BCS}$ on calf survival are scarce. However, if a low BCS is due to a nutritional stress, it may have a detrimental effect on immunoglobulin absorption [6, 11]. A reduced immunoglobulin transfer, in turn, may increase calf morbidity and mortality. Odde et al. [18] reported a decreasing concentration of immunoglobulins in the serum of calves when BCS at calving of primiparous cows was reduced from 6 to 3 on a 9-point scale. In this study, an explanation is difficult, since 9 of 11 calves were lost before the end of the first week after birth. Nevertheless, dam BCS at calving seems to be related to calf vigour.

Data relating to milk production and BCS are again limited. Goehring et al. [10] compared two groups of primiparous cows fed at 100 or $85 \%$ of NRC energy requirements. The low energy group lost 0.3 BCS units during a 130-d postpartum period, while the high energy cows maintained BCS. Daily milk production of the 100 and $85 \%$ energy groups averaged 6.0 and $5.1 \mathrm{~kg}$ at 60 days after calving, and 5.7 and $4.9 \mathrm{~kg}$ at 90 days after calving, respectively. Corresponding calf weights at $130 \mathrm{~d}$ after birth were 117.2 and $104.6 \mathrm{~kg}$, which was significantly different $(P<0.05)$. These results are not in accordance with our findings. Goehring et al. [10] reported milk yield values that were 14 to $30 \%$ lower than in BBDM cows, but this may be partly explained by the use of primiparous cows which have a lower milk production than mature cows.

\section{CONCLUSIONS}

It appears that the application of a body condition scoring system, which was not designed for double-muscled beef cows, can be a simple non-destructive technique in Belgian Blue breeding cows. It offers an indication of body reserves. Consequently, it allows appropriate dietary changes to be made in order to achieve a desirable body condition. The optimal range of BCS for BBDM cows may be 1.5-1.8, although it is not easy to define an optimum BCS, since a value at calving below 1.5 resulted in less open cows at 9 months after calving, while dams with a mean BCS of 1.74 yielded more milk and resulted in a better calf performance. Since the optimal range is small, it may be important to determine BCS as precise as possible.

\section{ACKNOWLEDGEMENTS}

This research project was financed by the Ministry of Small Enterprises, Traders and Agriculture, Administration for Research and Development, Brussels. The authors greatly acknowledge Koen Desomviele, and Marc De Paepe for their skilled technical assistance.

\section{REFERENCES}

[1] Agabriel J., Giraud J.M., Petit M., Détermination et utilisation de la note d'état d'engraissement en élevage allaitant, Bull. Tech. CRZV Theix INRA 66 (1986) 43-50.

[2] Beal W.E., Notter D.R., Akers R.M., Techniques for estimation of milk yield in beef cows and relationships of milk yield to calf weight gain and postpartum reproduction, J. Anim. Sci. 68 (1990) 937-943.

[3] Bearden H.J., Fuquay J.W., Nutritional Management, in: Bearden H.J., Fuquay J.W. (Eds.), Applied Animal Reproduction, Prentice Hall, Englewood Cliffs, NJ, USA, 1992, pp. 283-292.

[4] Bellows R.A., Short R.E., Effects of precalving feed level on birth weight, calving difficulty and subsequent fertility, J. Anim. Sci. 46 (1978) 1522-1528.

[5] Bishop D.K., Wettemann R.P., Spicer L.J., Body energy reserves influence the onset of luteal activity after early weaning of beef cows, J. Anim. Sci. 72 (1994) 2703-2708.

[6] Blecha F., Bull R.C., Olson D.P., Ross R.H., Curtis S., Effects of prepartum protein restriction in the beef cow on immunoglobulin content in blood and colostral whey and subsequent immunoglobulin absorption by the 
neonatal calf, J. Anim. Sci. 53 (1981) 1174 1180.

[7] Boadi D., Price M.A., The effects of pre- and early post-calving management on reproductive performance of beef cows, Can. J. Anim. Sci. 76 (1996) 337-342.

[8] Ferrell C.L., Garrett W.N., Hinman N., Growth, development and composition of the udder and gravid uterus of beef heifers during pregnancy, J. Anim. Sci. 42 (1976) 14771489.

[9] Fiems L.O., Van Caelenbergh W., Vanacker J.M., De Campeneere S., Seynaeve M., Prediction of empty body composition of double-muscled beef cows, Livest. Prod. Sci. 92 (2005) 249-259.

[10] Goehring T.B., Corah L.R., Higgins J.J., Effects of energy and lasalocid on productivity of first-calf heifers, J. Anim. Sci. 67 (1989) 1879-1888.

[11] Halliday R., Russel A.J.F., Williams M.R., Peart J.N., Effect of energy intake during late pregnancy and of genotype on immunoglobulin transfer to calves in suckler herds, Res. Vet. Sci. 24 (1978) 26-31.

[12] Houghton P.L., Lemenager R.P., Horstman L.A., Hendrix K.S., Moss G.E., Effects of body composition, pre- and postpartum energy level and early weaning on reproductive performance of beef cows and preweaning calf gain, J. Anim. Sci. 68 (1990) 14381446.

[13] Kilkenny J.B., Reproductive performance of beef cows, World Rev. Anim. Prod. 14 (1978) 65-74.

[14] Laflamme L.F., Connor M.L., Effect of postpartum nutrition and cow body condition at parturition on subsequent performance of beef cattle, Can. J. Anim. Sci. 72 (1992) 843-851.

[15] Looper M.L., Lents C.A., Vizcarra J.A., Wettemann R.P., Effects of body condition on luteal activity and estrus in postpartum beef cows, Animal Science Research Report, Oklahoma State University, Oklahoma, 1997, pp. 159-162.

[16] Lowman B.G., Scott N., Somerville S., Condition scoring of cattle. East of Scotland College of Agriculture, Bulletin No. 6, The Edinburgh School of Agriculture, Edinburgh, 1976.

[17] Morrison D.G., Spitzer J.C., Perkins J.L., Influence of prepartum body condition score change on reproduction in multiparous beef cows calving in moderate body condition, J. Anim. Sci. 77 (1999) 1048-1054.

[18] Odde K.G., Abernathy L.A., Greathouse G.A., Effect of body condition and calv- ing difficulty on calf vigor and calf serum immunoglobulin concentrations in two-yearold beef heifers, Beef Program Report, Colorado State University, Fort Collins, 1986, pp. 16-20.

[19] Richards M.W., Spitzer J.C., Warner M.B., Effect of varying levels of postpartum nutrition and body condition at calving on subsequent reproductive performance in beef cattle, J. Anim. Sci. 62 (1986) 300-306.

[20] Richards M.W., Wettemann R.P., Schoenemann H.M., Nutritional anestrus in beef cows: body weight change, body condition, luteinizing hormone in serum and ovarian activity, J. Anim. Sci. 67 (1989) 1520-1526.

[21] Selk G.E., Wettemann R.P., Lusby K.S., Oltjen J.W., Mobley S.L., Rasby R.J., Garmendia J.C., Relationship among weight change, body condition and reproductive performance of range beef cows, J. Anim. Sci. 66 (1988) 3153-3159.

[22] Spitzer J.C., Morrison D.G., Wettemann R.P., Faulkner L.C., Reproductive responses and calf birth and weaning weights as affected by body condition at parturition and postpartum weight gain in primiparous beef cows, J. Anim. Sci. 73 (1995) 1251-1257.

[23] SPSS, SPSS for Windows, Release 12.0, SPSS Inc., Chicago, IL, USA, 2003.

[24] Vandeplassche M., Bouters R., The impact of gynaecological and obstetrical problems resulting out of pregnancy and parturition, in: Karg H., Schallenberger E. (Eds.), Factors influencing fertility in the postpartum cow, Martinus Nijhoff Publishers, The Hague, 1982, pp. 30-44.

[25] Wagner J.J., Lusby K.S., Oltjen J.W., Rakestraw J., Wettemann R.P., Walters L.E., Carcass composition in mature Hereford cows: estimation and effect on daily metabolizable energy requirement during winter, J. Anim. Sci. 66 (1988) 603-612.

[26] Wright I.A., Rhind S.M., Russel A.J.F., Whyte T.K., McBean A.J., McMillen S.R., Effects of body condition, food intake and temporary calf separation on the duration of post-partum anoestrus period and associated LH, FSH and prolactin concentrations in beef cows, Anim. Prod. 45 (1987) 395402.

[27] Wright I.A., Russel A.J.F., Partition of fat, body composition and body condition score in mature cows, Anim. Prod. 38 (1984) 2332.

[28] Wright I.A., Russel A.J.F., The composition and energy content of empty body-weight change in mature cattle, Anim. Prod. 39 (1984) 365-369. 